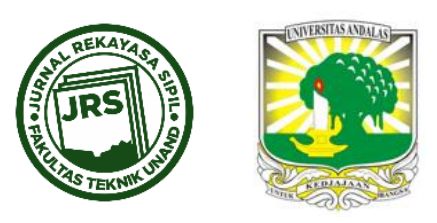

\title{
PERENCANAAN INTEGRASI LAYANAN OPERASIONAL ANTAR MODA RAILBUS DAN ANGKUTAN UMUM DI KOTA PADANG
}

\author{
MAIYOZZI CHAIRI $^{1}$, YOSSYAFRA $^{2}$, ELSA EKA PUTRI ${ }^{3}$ \\ ${ }^{1}$ Prodi Magister Teknik Sipil, Fakultas Teknik, Universitas Andalas (maiyozzichairi5o@gmail.com) \\ ${ }^{2}$ Jurusan Teknik Sipil, Fakultas Teknik, Universitas Andalas ( $₫$ yossyafra@ft.unand.ac.id) \\ 33urusan Teknik Sipil, Fakultas Teknik, Universitas Andalas (elsaeka@ft.unand.ac.id) \\ Naskah diterima : 3 Desember 2016. Disetujui: 9 Februari 2017. Diterbitkan : 4 Maret 2017
}

\begin{abstract}
ABSTRAK
Semakin meningkatnya kebutuhan masyarakat menyebabkan akses jalan untuk menunjang kelancaran perpindahan dari suatu tempat ke tempat lain semakin tinggi. Penelitian ini bertujuan untuk menentukan skenario perencanaan secara operasional dalam menyesuaikan moda transportasi Railbus yang terintegrasi dengan moda angkutan umum sehingga diharapkan pemanfaatan dan pelayanannya bisa berjalan dengan baik, diterima oleh semua masyarakat, dan tercipta transportasi multimoda yang efektif dan efisien. Penelitian ini juga didukung oleh parameter analisis perencanaan yaitu waktu tempuh perjalanan dan biaya perjalanan. Di dalam perencanaan menggunakan identifikasi daerah tangkapan (Catchment Area) pada 5 Stasiun/Halte Railbus dengan asumsi radius $+2000 \mathrm{~m}$ dan daerah tangkapan (Catchment Area) untuk rute angkot dengan asumsi $+500 \mathrm{~m}$ ke daerah sekitar. Secara metodologis penelitian ini menggunakan pendekatan kuantitatif, deskriptif dan perencanaan yang merujuk pada hasil survey pengamatan operasional kombinasi multimoda dalam kondisi angkot eksisting maupun setelah multimoda. Hasil penelitian menunjukkan bahwa dari 39 zona yang telah ditetapkan batasannya dan sudah diidentifikasi, maka didapatkan sekitar 18 zona asal tujuan perjalanan yang berpeluang untuk multimoda dan terbagi menjadi 180 kombinasi asal tujuan perjalanan dengan persentase sekitar 11,83 \% dari O-D Matrix secara keseluruhan. Pada analisis variabel waktu perjalanan didapatkan sebanyak 15 zona asal dan 18 zona tujuan yang berpeluang multimoda terdiri dari 77 kombinasi asal tujuan perjalanan atau sekitar $42,77 \%$ dari keseluruhan kombinasi asal tujuan perjalanan dan 5,06\% dari O-D Matrix secara keseluruhan. Sedangkan pada analisis variabel biaya perjalanan didapatkan sebanyak 15 zona asal dan 14 zona tujuan yang berpeluang multimoda terdiri dari 78 kombinasi asal tujuan perjalanan atau sekitar $43,33 \%$ dari keseluruhan kombinasi asal tujuan perjalanan dan 5,13\% dari O-D Matrix secara keseluruhan. Tahap akhir dilakukan berupa perencanaan terintegrasi dari semua skenario yang sudah ditetapkan yaitu berupa perencanaan yang diharapkan terintegrasi secara waktu, rute, biaya, dan fasilitas penunjang.
\end{abstract}

Kata kunci : Integrasi, Transportasi, Railbus, Kombinasi perjalanan, Multimoda 


\section{PENDAHULUAN}

Negara Indonesia merupakan sebuah negara berkembang. Sehingga perkembangan dan pembangunan di berbagai aspek selalu ditingkatkan dari waktu ke waktu. Tidak terkecuali pada sektor perhubungan dan transportasi. Semakin meningkatnya kebutuhan masyarakat menyebabkan akses untuk menunjang kelancaran perpindahan dari suatu tempat ke tempat lain semakin tinggi. Tahun 2002 jumlah kendaraan bermotor di kota Padang mengalami kenaikan sebesar $12,67 \%$. Selanjutnya persentase kenaikan jumlah kendaraan bermotor berturut-turut dari tahun 2006 sampai dengan tahun 2008 adalah $12,15 \%$ dan 23,87\%. Terkonsentrasinya hampir seluruh aktivitas umum (public activity) di pusat kota, telah menimbulkan kongesti pada jam sibuk (peak hour) pagi, siang, dan sore hari. Kongesti yang diikuti oleh terjadinya kemacetan. Sehingga juga mengakibatkan waktu tempuh menggunakan angkutan umum menjadi lama. Sedangkan untuk karakteristik penggunaan moda transportasi di kota Padang adalah 45.47\% menggunakan angkutan umum, $50.67 \%$ kendaraan pribadi (27.34\% sepeda motor, $23.33 \%$ mobil pribadi), sedangkan sisanya menggunakan taksi dan lain-lain (RITK Kota Padang Tahun, 2010). Diperkirakan dengan sedikit penyesuaian seperti lintasan rute ataupun akses, semua moda angkutan transportasi khususnya angkutan umum bisa semakin efektif dan efisien mengangkut penumpang, dan warga pun tertarik naik angkutan umum/massal. Moda Railbus pun bisa berfungsi sebagai feeder/pengumpan sehingga menjadi suatu keterpaduan moda yang efektif dan efisien.

Rumusan masalah dalam penelitian ini yaitu bagaimanakah menentukan perencanaan operasional dalam menyesuaikan moda transportasi Railbus yang terintegrasi dengan angkutan umum dan dianalisis menggunakan variabel waktu dan biaya perjalanan, sehingga tercipta perjalanan yang efektif dan efisien. Sesuai dengan rumusan masalah, maka tujuan yang ingin dicapai pada penelitian ini yaitu untuk merencanakan penyesuaian operasional moda transportasi Railbus yang terintegrasi dengan moda angkutan umum sehingga pemanfaatannya dan pelayanannya bisa berjalan dengan baik dan diterima oleh masyarakat.

\section{TINJAUAN PUSTAKA}

\subsection{Integrasi Moda Transportasi}

Integrasi secara umum memiliki arti pembauran atau keterpaduan hingga menjadi kesatuan yang utuh atau bulat.Sedangkan moda adalah bentuk atau jenis. Indonesia merupakan negara kepulauan sehingga tidak bisa dihindari perlunya pertukaran moda transportasi dalam suatu perjalanan, baik untuk penumpang maupun barang dari tempat asal menuju tempat tujuan. Biaya transportasi dari tempat asal ke tempat tujuan ini merupakan kombinasi dari biaya transportasi setiap moda ditambah dengan biaya transit dari suatu moda ke moda lainnya (Tamin 2008). Padahal, integrasi jaringan merupakan kunci kesuksesan sistem pelayanan transportasi publik di suatu wilayah atau kota (Neumann dan Nagel, 2011). Hal ini dikarenakan dengan sistem jaringan transportasi publik yang terintegrasi dapat ditentukan rute jaringan terbaik yang tidak hanya didasarkan pada permintaan kebutuhan perjalanan masyarakat tetapi juga mekanisme jangkauan pelayanan yang optimal (Murray, 2001; Fernandez et al, 2008; Hadas dan Ceder, 2010; Cortes et al, 2011). Bahkan, integrasi jaringan dapat berdampak pada timbulnya integrasi yang lain, seperti integrasi fisik, jadwal, dan tarif (Currie dan Bromley, 2005; Potter, 2010; Hadas dan Ranjitkar, 2012). Jadi Integrasi moda transportasi bisa diartikan keterpaduan secara utuh dari jenis atau bentuk (angkutan) yang digunakan untuk memindahkan orang dan/ barang dari satu tempat (asal) ketempat lain (tujuan). 


\subsection{Indikator Penunjang Integrasi Moda Transportasi}

1. Waktu Tempuh Perjalanan : Menurut Tamin (2008) waktu tempuh adalah salah satu faktor utama yang harus diperhatikan dalam transportasi.Waktu tempuh juga merupakan daya tarik utama dalam pemilihan moda yang digunakan oleh suatu perjalanan (manusia ataupun barang). Jelas bertambahnya waktu tempuh pada suatu moda akan menurunkan jumlah penggunaan moda tersebut dan dengan sendirinya pula akan menurunkan tingkat pendapatan ataupun pelayanannya.

2. Biaya Perjalanan : Menurut Tamin (2008) untuk perjalanan yang memerlukan beberapa moda transportasi, factor lainnya yang lebih menentukan (selain waktu tempuh) adalah biaya transit (biaya perpindahan barang atau penumpang).Dapat dilihat pada gambar bahwa untuk menekan biaya transportasi, baik untuk pergerakan penumpang maupun barang dalam system transportasi antarmoda yang terpadu, hal yang perlu diperhatikan adalah usaha penghematan biaya transit dari suatu moda ke moda lainnya.Untuk itu perlu dibangun fasilitas sarana dan prasarana di tempat perpindahan barang atau penumpang ataupun pengalihan rute salah satu moda agar dapat berlangsung dengan cepat, aman, murah, dan nyaman sehingga biaya transit dapat ditekan sekecil mungkin.

\subsubsection{Konsep Angkutan Umum Multimoda}

1. Moda Penghubung (Connecting Modes) : Moda penghubung didefinisikan sebagai penghubung sebelum dan sesudah moda utama yang sedang digunakan (Krygsman 2004). Moda sebelum atau "access mode" didefinisikan sebagai moda yang digunakan dari rumah ke tempat perhentian angkutan umum (busstop/station/terminal) seperti jalan kaki, sepeda, mobil atau motor, dan taxi. Moda sesudah atau "egress mode" didefinisikan sebagai moda yang digunakan dari tempatperhentian (bus-stop/station/terminal) ke tempat tujuan.

2. Moda Utama (Main Modes) : Moda utama biasanya yang digunakan dalam perjalanan paling panjang dan paling lama dari moda lainnya. Sudah banyak penelitian dan pengembangan moda utama ini, tentang pengembangan alat angkutan umum, sinkronisasi jadwal antara moda satu dengan lainnya.

3. Jaringan Multimoda (Multimodal Network: Main Route, Feeder Route) : Hal yang paling mendasar dari komponen multimoda adalah tersedianya jaringan yang terpadu antara moda moda (multimodal network). Nes (2002) meneliti tentang konsekuensi dari perjalanan multimoda untuk sebuah perancangan jaringan multimoda. Karakteristik utama dari jaringan multimoda adalah memiliki jaringan yang tersambung antar jenis (moda) dan mengenal adanya perbedaan level atau jenjang dari jaringan. Jaringan level tertinggi adalah untuk kecepatan tinggi dan akses terbatas sedangkan tingkatan yang terendah adalah untuk jarak pendek, adanya akses ke jaringan yang lebih tinggi, kecepatan rendah, kepadatan jaringan yang lebih tinggi. Bagaimana membuat jaringan multimoda yang efisien, bagaimana pengaruh multimoda pada rancangan jaringan transportasi. Faktor utama yang mempengaruhi angkutan multimoda adalah panjangnya trip, daerah yang dituju dan maksud perjalanan.

4. Fasilitas Peralihan Moda (Transfer Point) : Fasilitas peralihan moda juga sangat penting untuk menarik penumpang angkutan pribadi yang dapat berintegrasi dengan angkutan umum. Fasilitas parkir yang cukup untuk menampung kebutuhan akan dapat menarik penumpang angkutan pribadi untuk 
meninggalkan mobil pribadinya ditempat ini dan selanjutnya menyambung dengan angkutan umum. Terlebih lagi jika ongkos parkir dipusat kota mahal.

5. Fasilitas Peralihan Moda Dengan Jaringan Berbeda (Intermodal Transfer Point) : Fasilitas Intermodal Transfer Point adalah sangat penting karena merupakan titik sambung antara dua jenis moda dari dua jenis jaringan yang berbeda. Contohnya antara jaringan sungai dan jaringan jalan, atau kereta api. Spek (2001) sudah mengkaji tentang teori pengembangan arsitektur bangunan transfer antar moda (Intermodal Transfer Point). Hasilnya adalah konsep rancangan bangunan arsitektur sistem multimoda yang terpadu, terkombinasi dan fleksibel dan mempunyai jaringan multilayer.

6. Peraturan : Peraturan sebagai alat pengontrol kinerja angkutan umum juga sebaiknya berubah kearah multimodality. Peraturan tentang moda utama, moda pengumpan, moda sebelum dan sesudah, ketersambungan dengan moda lain melalui transfer point dan intermodal transfer point belum ada. Akan tetapi kebijakan kearah ini belum tersentuh. Garrison (2006) menyajikan dua model kebijakan, yaitu model kebijakan experiential dan conventional. Tambahan lagi, pembuatan kebijakan harus disiapkan sebelum planning, deployment, management, action dan reaction. Pada kenyataannya, kebijakan diputar balik urutannya.

\section{METODOLOGI PENELITIAN}

Secara metodologis penelitian ini menggunakan pendekatan kuantitatif, penjelasan, dan perencanaan yang merujuk pada hasil di lapangan serta survey pengamatan kondisi operasional dalam keadaan eksisting dan setelah memakai modaRailbus (multimoda). Menurut Sugiyono (2008) Metode kuantitatif disebut sebagai metode positivistic karena berlandaskan pada filsafat positivisme. Metode ini sebagai metode ilmiah/scientific karena telah memenuhi kaidah-kaidah ilmiah yaitu konkrit/empiris, obyektif, terukur, rasional, dan sistematis. Metode ini disebut kuantitatif karena data penelitian berupa angka-angka dan analisis.

\subsection{Tahapan Penelitian}

Keterpaduan layanan antarmoda angkutan umum dan Railbus Kota Padang dibagi menjadi beberapa tahapan. Tahapan awal merupakan tahapan untuk mengidentifikasi rute trayek angkutan umum, mengidentifikasi operasional transportasi yang ada pada wilayah yang terintegrasi (screening matrix asal tujuan perjalanan), serta pembagian zona (batas administrasi). Tahapan selanjutnya memasukkan variabel ukur waktu dan biaya perjalanan sebagai ukuran kemudahan dalam melakukan perjalanan.

\subsection{Lingkup Penelitian}

Penelitian ini mengambil kawasan Kota Padang yang terdiri dari beberapa zona perjalanan (36 Zona), 45 trayek angkutan umum, dan memakai jaringan rel kereta api dari Simpang Haru ke Lubuk Buaya.

\subsection{Teknik Pengumpulan Data}

1. Data Primer : Menggambarkan daerah tangkapan tiap-tiap trayek angkutan umum dan halte Railbus yang ada. Digunakan untuk menentukan kombinasi asal tujuan perjalanan yang berpeluang multimoda. Lalu berupa survey lapangan untuk variabel waktu perjalanan dan biaya perjalanan angkutan umum yang 
mewakili tiap-tiap trayek, survey waktu dan biaya kereta api yang sedang beroperasi sekarang.

2. Data Sekunder :

Tabel 1. Pengumpulan Data Sekunder

\begin{tabular}{|c|c|c|c|}
\hline No & Jenis Data & Instansi & Kegunaan Data \\
\hline 1 & $\begin{array}{l}\text { Data peta jaringan transportasi, } \\
\text { dan jumlah penduduk kota } \\
\text { Padang }\end{array}$ & $\begin{array}{lrr}\text { BPS } & \text { dan } \\
\text { BAPPEDAKota Padang } \\
\text { (Publikasi di Site } \\
\text { Instansi) }\end{array}$ & 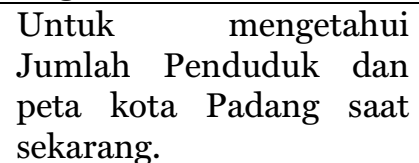 \\
\hline 2 & $\begin{array}{l}\text { Data MAT, Pembagian Zona } \\
\text { Padang, RITK,Trayek angkutan } \\
\text { umum }\end{array}$ & $\begin{array}{l}\text { Dishub Kominfo Kota } \\
\text { Padang, dan RITK } \\
\text { Padang }\end{array}$ & \begin{tabular}{lr} 
Untuk & \multicolumn{2}{r}{ mengetahui } \\
perjalanan & antar \\
sebagai & zona \\
perencanaan, dan analisis \\
variabel
\end{tabular} \\
\hline
\end{tabular}

\subsection{Alur Pelaksanaan Penelitian}

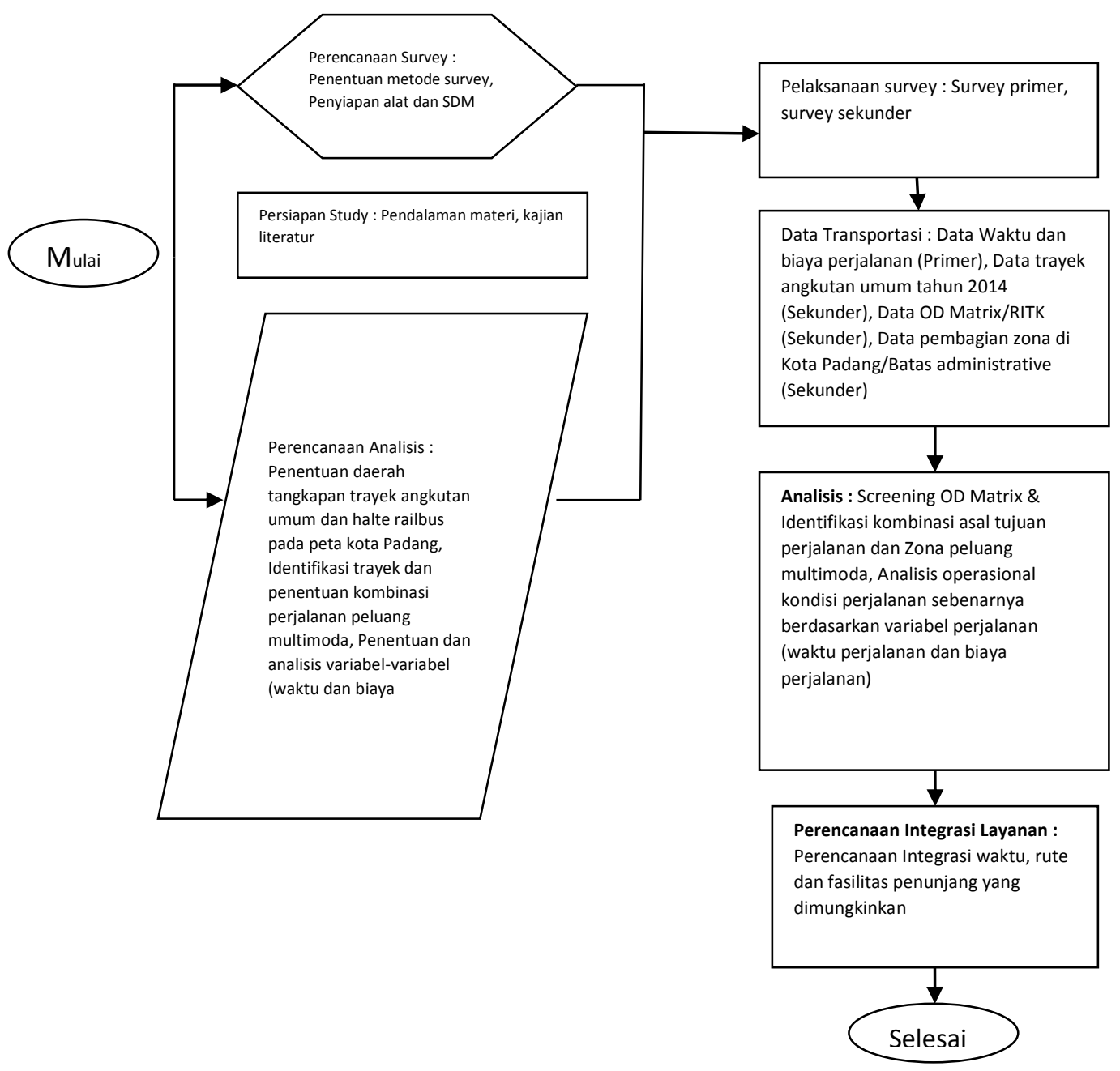

Gambar 1. Alur Pelaksanaan Penelitian 


\section{PEMBAHASAN}

\subsection{O-D Matrix (Matriks Asal Tujuan Perjalanan)}

Matrix Asal Tujuan perjalanan adalah basis dasar dari perencanaan transportasi apapun. OD Matrix bertujuan untuk melihat kondisi bangkitan dan tarikan, dan screening perjalanan orang perhari pada setiap zona (sebanyak 39 zona) yang telah ditentukan pada RITK Padang. O-D Matrix yang diambil ini bersumber dari hasil Survey Wawancara Pinggir Jalan/Road Street Interview (RSI) dan Wawancara Rumah/Home Interview (HI) berdasarkan Laporan Akhir RITK tahun 2010 yang secara umum melakukan survey perjalanan pada angkutan umum, kendaraan pribadi, taksi, sepeda motor, dan moda lainnya (lihat gambar a di lampiran).

\subsection{Layanan Angkutan Umum+Railbus dan Angkutan Umum+Angkutan Umum Berdasarkan Variabel Waktu Tempuh Perjalanan}

Untuk waktu perjalananan Railbus diasumsikan sama dengan operasional kereta api Padang-Pariaman yang ada sekarang : Hasil Survey yaitu Stasiun Simpang Haru (Waktu Tunggu 3 menit) - Halte Alai = 4 menit, Halte Alai (Waktu Tunggu 2 menit) - Halte Basko = 9 menit, Halte Basko (WT 3 menit) - Stasiun Tabing = 8 menit, Stasiun Tabing (WT 3 menit) - Halte Lubuk Buaya = 7 menit, Halte Lubuk Buaya (WT 2 menit).

Screening berdasarkan waktu tempuh perjalanan yang dilakukan secara keseluruhan diperoleh hasil Zona Asal perjalanan adalah sebanyak 15 Zona dan Zona Tujuan perjalanan yang sebanyak 18 Zona, terbagi sebanyak 77 kombinasi asal tujuan perjalanan berpeluang. Sehingga didapat persentase zona peluang asal tujuan perjalanan multimoda menurut waktu perjalanan dibandingkan peluang asal tujuan perjalanan secara keseluruhan menjadi : $77 / 180 \times 100 \%=42,77 \%$ dari kombinasi zona asal tujuan perjalanan keseluruhan. Sedangkan persentase zona peluang asal tujuan perjalanan berdasarkan waktu perjalanan dibandingkan asal tujuan perjalanan dari O-D Matrix secara keseluruhan adalah 77/1521 x $100 \%=5,06 \%$ (lihat gambar b di lampiran).

\subsection{Layanan Angkutan Umum+Railbus dan Angkutan Umum+Angkutan Umum Berdasarkan Variabel Biaya Perjalanan}

Asumsi biaya perjalanan yang dipakai untuk multimoda adalah 2 halte terdekat yaitu Rp. 2000, dan halte selanjutnya adalah Rp.3000 atau yang diasumsikan sama dengan harga kereta api Padang-Pariaman yang beroperasi sekarang. Sedangkan tarif angkot mengikuti tarif normal yaitu Rp. 4000, Rp. 3500, dan Rp. 3000 tergantung jarak.

Screening berdasarkan biaya perjalanan yang dilakukan secara keseluruhan diperoleh Zona Asal perjalanan yang berpeluang sebanyak 15 Zona dan Zona Tujuan perjalanan sebanyak 14 Zona, terbagi sebanyak 78 kombinasi asal tujuan perjalanan yang berpeluang. Sehingga persentase zona peluang asal tujuan perjalanan multimoda menjadi : 78/180 x 100\% = $43,33 \%$ dari zona asal tujuan perjalanan keseluruhan. Sedangkan persentase zona peluang asal tujuan perjalanan berdasarkan biaya perjalanan dibandingkan asal tujuan perjalanan dari O-D Matrix secara keseluruhan adalah 78/1521 x 100\% = 5,13\% (lihat gambar c di lampiran). 


\subsection{Perencanaan Integrasi Layanan}

Dari hasil survey dan analisis data yang telah dilakukan, dalam tahap akhir perlu untuk mendeskripsikan suatu analisis perencanaan integrasi layanan yang tercakup kepada Integrasi waktu, Integrasi rute, maupun Integrasi fasilitas penunjang.

\subsubsection{Integrasi Waktu}

Integrasi atau keterpaduan dalam segi waktu adalah menentukan kapan sebaiknya multimoda itu dilakukan. Hal ini disebabkan karena jadwal Railbus tidak mungkin bisa dioperasikan setiap waktu (terjadwal) dan mempertimbangkan gerbong Railbus hanya 3 buah yang memuat lebih kurang 150 penumpang, maka diharapkan jadwal yang bisa diprediksi dan baik untuk integrasi waktu dalam multimoda. Sementara untuk operasional angkutan umum bisa dilakukan kapan saja dengan waktu tertentu (tidak terjadwal). Ada 2 alternatif perencanaan yaitu :

1. Jadwal keberangkatan Railbus direncanakan dalam Peak Hour yang dianggap merupakan jam orang melakukan asal tujuan perjalanan yang tinggi. Yaitu 3 kali PP (Pulang Pergi) dalam sehari pada pukul 06.00, 12.00, dan 17.00.

2. Jadwal keberangkatan Railbus direncanakan setiap 3 jam atau 2 jam sekali, dengan PP (Pulang pergi) setiap 1 kali perjalanan, dimulai pada pukul 6 untuk jadwal pagi. Maka diprediksi jadwal dalam 1 hari itu dari Simpang Haru adalah pukul 06.00, 09.00, 12.00, 15.00, 17.00, dan terakhir 20.00.

\subsubsection{Integrasi Rute}

Integrasi dalam hal ini adalah perubahan rute angkutan umum yang memungkinkan melakukan peralihan moda (Transfer Point) yang efektif dan efisien. Yaitu pada titik tertentu yang dekat dengan stasiun dan shelter Railbus yang ada.

1. Angkot yang menurunkan penumpang di depan stasiun Simpang Haru dimungkinkan untuk merubah/menambah rute memasuki stasiun sehingga memudahkan akses naik turun penumpang. Panjang Deviasi dari Rute eksisting +250 m masuk dan +250 m keluar.

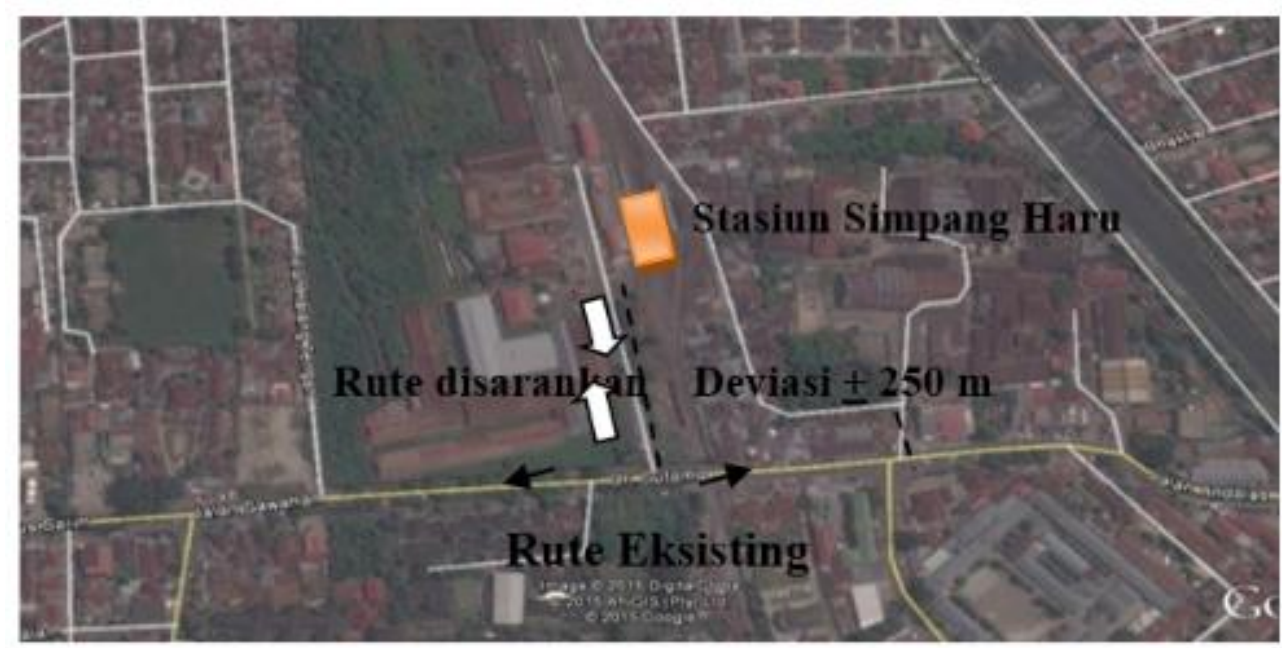

Gambar 2. Deviasi Rute melewati Stasiun Simpang Haru 
2. Dimungkinkan perubahan rute dan akses untuk angkot dengan kondisi existing melalui simpang alai sehingga disarankan masuk melewati halte Railbus alai atau pasar alai. Panjang Deviasi dari Rute eksisting $+375 \mathrm{~m}$.

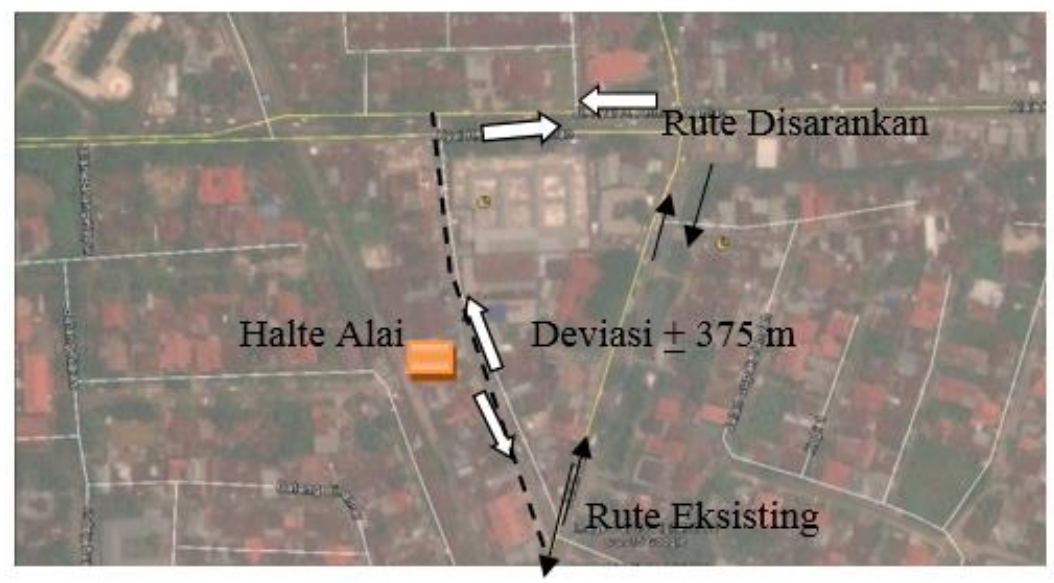

Gambar 3. Deviasi Rute melewati Halte Alai

3. Angkot yang mengadopsi rute daerah Simpang Kalumpang dimungkinkan bisa merubah dan menambah rutenya sampai ke arah halte Lubuk Buaya. Panjang Deviasi dari Rute eksisting $+600 \mathrm{~m}$.

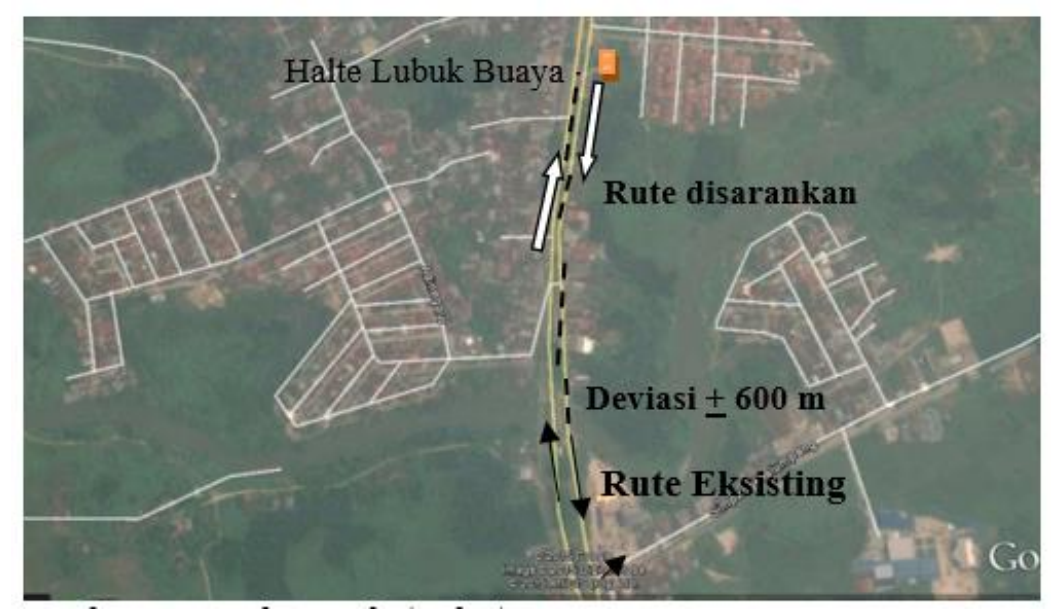

Gambar 4. Deviasi Rute melewati Halte Lubuk Buaya

4. Untuk Halte Basko, Stasiun Tabing, dan Halte Lubuk Buaya sudah bersisian dengan Rute Angkutan Umum (Modal Split), sehingga tidak ada deviasi dan angkot akan berhenti pada tiap-tiap titik transfer point tersebut. Panjang Deviasi dari Rute eksisting tidak Ada.

\subsubsection{Integrasi Fasilitas Penunjang}

Integrasi dalam hal ini diperlukan, karena menyangkut prasarana peralihan ataupun penunjang operasional moda yang akan menggunakannya.

1. Dimungkinkan menambah halte Railbus pada wilayah Lapai, Simpang Tunggul Hitam, dan wilayah Pasir Jambak sehingga menambah kemudahan kombinasi 
asal tujuan dan potensi perjalanan, terintegrasi dengan angkot dadok dan yang mendekati rute tersebut. Dengan syarat waktu berhenti Railbus juga ditambah pada masing-masing halte.

2. Dimungkinkan untuk menambah fasilitas peralihan moda disetiap Transfer Point. Seperti menambah kapasitas atau membuka ruang tunggu dan parkir untuk angkot ke halte atau terminal, sehingga diharapkan menarik penumpang untuk beralih ke transportasi publik yang multimoda.

\section{KESIMPULAN DAN SARAN}

\subsection{Kesimpulan}

1. Dimungkinkan untuk terjadinya perencanaan integrasi layanan operasional multimoda berdasarkan waktu, rute, dan fasilitas penunjang.

2. Kombinasi asal-tujuan perjalanan Multimoda dengan variabel waktu perjalanan mendapatkan 15 Zona asal dan 18 Zona tujuan perjalanan yang berpeluang dan terbagi menjadi 77 kombinasi asal tujuan perjalanan dari 180 kombinasi perjalanan secara keseluruhan.

3. Kombinasi asal-tujuan perjalanan Multimoda dengan variabel biaya perjalanan didapat 15 Zona asal dan 14 Zona tujuan perjalanan yang berpeluang dan terbagi menjadi 78 kombinasi asal tujuan perjalanan secara keseluruhan.

4. Persentase zona asal tujuan perjalanan multimoda yang memiliki peluang adalah 11,83\% (180 kombinasi asal tujuan perjalanan) dari zona O-D Matrix secara keseluruhan (1521 asal tujuan perjalanan). Persentase zona peluang asal tujuan perjalanan multimoda berdasarkan waktu perjalanan yaitu 42,77\% (77 kombinasi asal tujuan perjalanan), dan berdasarkan biaya perjalanan 43,33\% (78 kombinasi asal tujuan perjalanan) dari keseluruhan zona O-D yang berpeluang (180 kombinasi asal tujuan perjalanan).

5. Persentase zona peluang dari keseluruhan O-D matrix yang berjumlah 1521, untuk asal tujuan perjalanan yaitu $5,06 \%$ berdasarkan waktu (77 kombinasi asal tujuan perjalanan) dan $5,13 \%$ berdasarkan biaya (78 kombinasi asal tujuan perjalanan).

\subsection{Saran}

\section{Untuk Peneliti Lanjutan}

Perlu adanya pengujian dan perencanaan ulang apabila Railbus sudah beroperasi dan memberikan dampak yang signifikan, dilakukan sebuah penelitian untuk skenario integrasi biaya menggunakan inovasi baru, dan penelitian untuk menentukan analisis potensi demand.

\section{Untuk Pemerintah Daerah dan BUMN}

Jadwal keberangkatan Railbus yang bisa diprediksi sangat diperlukan agar tercipta integrasi transportasi yang efektif dan efisien, dan diharapkan juga terintegrasi dengan moda lainnya.

\section{Untuk Masyarakat Kota Padang}

Perlu mempertimbangkan moda yang efektif dan efisien, sehingga nanti bisa beralih ke moda transportasi publik. 


\section{DAFTAR KEPUSTAKAAN}

Abbas, S.H (2008), Manajemen Transportasi, Rajawali Pers, Jakarta.

Black, J.A (1981), Urban Transport Planning : Theory and Practice, Cromm Helm, London.

BMARTS (1996), Bandung Metropolitan Area Urban \& Sub-Urban Railway Transportation System, Final Report, Directorate General of Land Transportation, Department of Communications.

Buchari, E. (2008), Angkutan Umum Multimoda, Alternatif Perencanaan Transportasi yang Sustainable, Jurnal Khusus FSTPT Volume 3, FSTPT: Jakarta.

Christian R.Simanjuntak, dan Medis. (2012), Pengaruh Metode Keandalan Waktu Perjalanan Dalam Pemilihan Waktu Pergerakan, Universitas Sumatera Utara, Medan.

Cortes, Christian E., Diaz, Sergio Jara, Tirachini, Alejandro (2011), "Integrating Short Turning and Deadhealing in The Optimization of Transit Services", Transportation Research Part A, Vol. 45, hal. 419-434.

Davidson, K.B. (1966), A Flow Travel-Time Relationship for Use in Transport Planning, Proceedings of Australian Road Research Board, 3, Part 1.

Daamen, Winnie. (2004), Modelling Passenger Flows in Public Transport Facilities, PhD Dissertation-TRAIL-Thesis Series T2004/6, the Netherlands TRAIL Research School, DUP Science, Delft University Press, Delft.

Delta, T.W, (1997), Contoh Representasi Wilayah Kajian, Jakarta.

Djoko, Setijowarno. (2008), Integrasi Moda Kereta Api Untuk Operasi Angkutan Massal Kommuter di Wilayah Kedungsepur, Universitas Katolik Soegijapranata, Semarang.

Garrison, L.W, Levinson, M.D. (2006), Transportation Experience-Policy, Planningand Deployment, Oxford University Press, Oxford.

Giannopoulos. G.A. (1989), Bus Planning and Operation in Urban Areas: A Practical Guide.

Hadas, Y, dan A. Ceder. (2010), Definition of Planned and Unplanned Transfer of Public Transport Service and User Decision to Use Routes With Transfers, Journal of Public Transportation, New Zealand

Hadas, Y, dan P. Ranjitkar. (2012), Modeling Public-Transit Connectivity With Spatial Quality-ofTransfer Measurement, Journal of Transport Geography.

IHT dan DTp, (1987), Kriteria utama yang disarankan dalam pembagian daerah kajian.

Kanafani, A. (1983), Transportation Demand Analysis, Mc-Graw Hill Kogashuka Ltd, Tokyo.

Krygsman, S. (2004), Activity and Travel Choice(s) in Multimodal Public Transport Systems, PhD Dissertation, the Urban and Regional Research Centre Utrecht (URU), Utrecht.

Kusbiantoro. (2005), Potensi dan Tata Ruang Daerah dan Konsistensinya dengan Tata Ruang Nasional, HKI Indonesia, Jakarta.

Manheim, L., M., (1979), Fundamental Transportation Systems Analysis, The MIT Press, Cambridge.

Master Plan Jaringan Transportasi Perkotaan Pada Kawasan Aglomerasi PALAPA

Morlok, E.K., (1991), Pengantar Teknik dan Perencanaan Transportasi, Erlangga, Jakarta.

Mulyono, A.T, (2012), Transmedia Transportasi Multimoda Majalah Kementrian Perhubungan ,Jakarta.

Murray, A.T, (2001), Strategic Analysis of Public Transport Coverage,Socio-Economic Planning Sciences, Berlin.

Nazir, M. (2014), Metode Penelitian, Ghalia Indonesia, Bogor.

Nes, R. (2002), Design of Multimodal Transport Network, a hierarchical approach, TRAIL Thesis Series, Delft University Press, The Netherlands.

Neumann. A, dan Nagel. K. (2011), A paratransit-inspired evolutionary process for public transit network design, Annual Meeting Preprint-Ähnliche Artikel-Alle 4 Versionen, Berlin.

Ohta, K., (1998), TDM Measures Toward Sustainable Mobility, Journal of International Association Of Traffic And Safety Sciences.

Padang Dalam Angka 2014. Badan Pusat Statistik Kota Padang.

Peraturan Menteri Perhubungan R.I, Nomor 49 tahun 2005 tentang Sistem Transportasi Nasional (SISTRANAS). 
Peraturan Menteri Perhubungan RI No 69 Tahun 2014 tentang Pedoman Perhitungan dan Penetapan Tarif Angkutan Orang dengan Kereta Api.

Preston, Jonathan. (1990), Demand Forecasting For New Local Rail Stations and Services, Journal Of Transport Economic and Policy, University of Leeds.

Rozalinda, T. (2004), Kajian Jaringan Pelayanan Angkutan Umum Penumpang Dalam Kota di Kota Solok, Universitas Diponegoro, Semarang.

Rencana Induk Jaringan Transportasi Kota Padang (RITK), (2010).

Ryu, S. (2011), Investigating Travel Time Reliability Measures in Toll Design Problem, EASTS.

Sabdo, (2012), Keamanan Bertransportasi, ISSUU.com

Setiawan, H. (2012), Kualitas Layanan Transportasi,Universitas Indonesia, Jakarta.

Singarimbun, M. dan Effendi, S. (1999), Metode Penelitian Survey, LP3ES, Jakarta.

Sistem Transportasi Nasional (Sistranas). (2012), Kementrian Perhubungan, Jakarta.

SK Dirjen Perhubungan No. 687 Tahun 2002 tentang Pedoman Teknis Penyelenggaraan Angkutan Umum Perkotaan.

Skinner, Potter, (2000), Public Transport System, Landor, London.

Spek, S, C, Van Der, (2001), The Development of Architectural Design Theory Specifically Directed at Intermodal Transfer Building for Multimodal Passenger Transportation, PhD Thesis, Delft University, The Netherlands.

Sugiyono, (2008), Metode Penelitian Kuantitatif Kualitatf dan R\&D, Penerbit Alfabeta, Bandung.

Tamin, O.Z, (2008), Perencanaan, Pemodelan, \& Rekayasa Transportasi, Penerbit ITB, Bandung.

Warpani, S. (2002), Pengelolaan Lalu Lintas dan Angkutan Jalan, Penerbit Institut Teknologi Bandung, Bandung.

Wolf, Thomas., http://creative commons.org/licenses/by-sa/2.5.

Yulianti, dan Amalia, R. (2013), Konsep Integrasi Moda Transportasi Publik di Kota Surabaya Berdasarkan Preferensi Masyarakat, Institut Negeri Surabaya, Surabaya.

\section{LAMPIRAN}

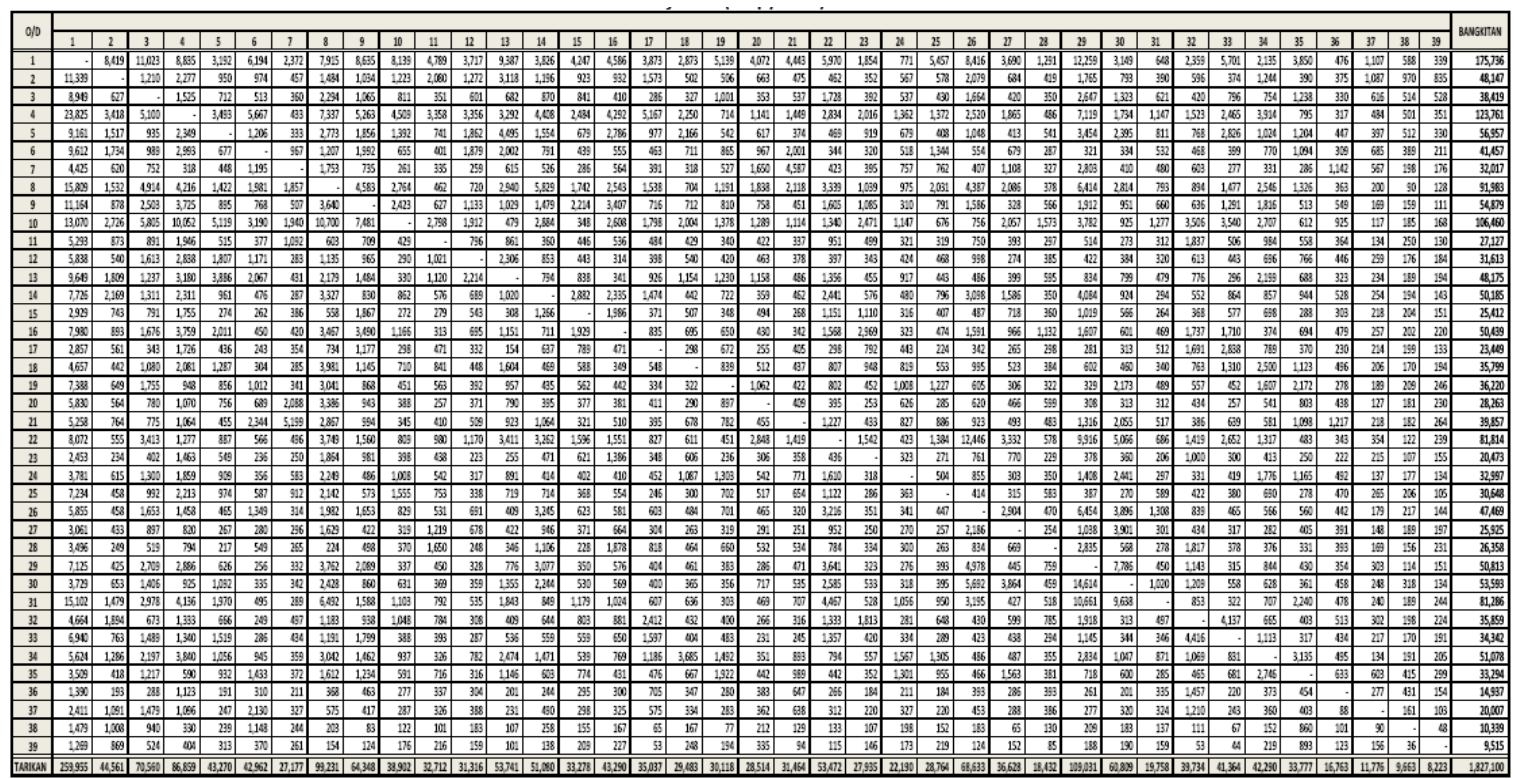

Gambar a. O-D Matrix Kota Padang 


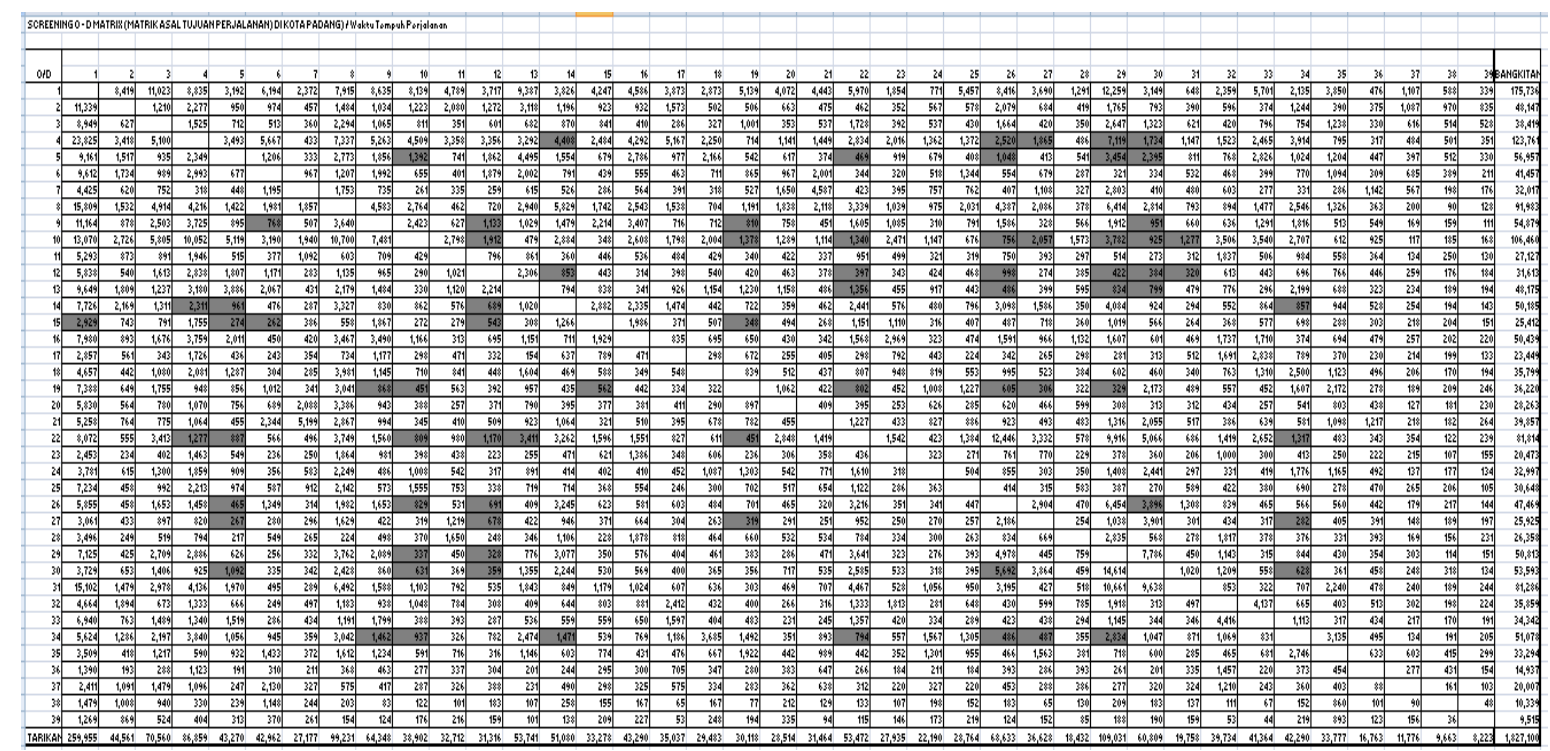

Gambar b. Screening O-D Matrix Berdasarkan Waktu Tempuh Perjalanan. (Yang diarsir hitam merupakan Zona yang berpeluang multimoda berdasarkan waktu tempuh perjalanan)

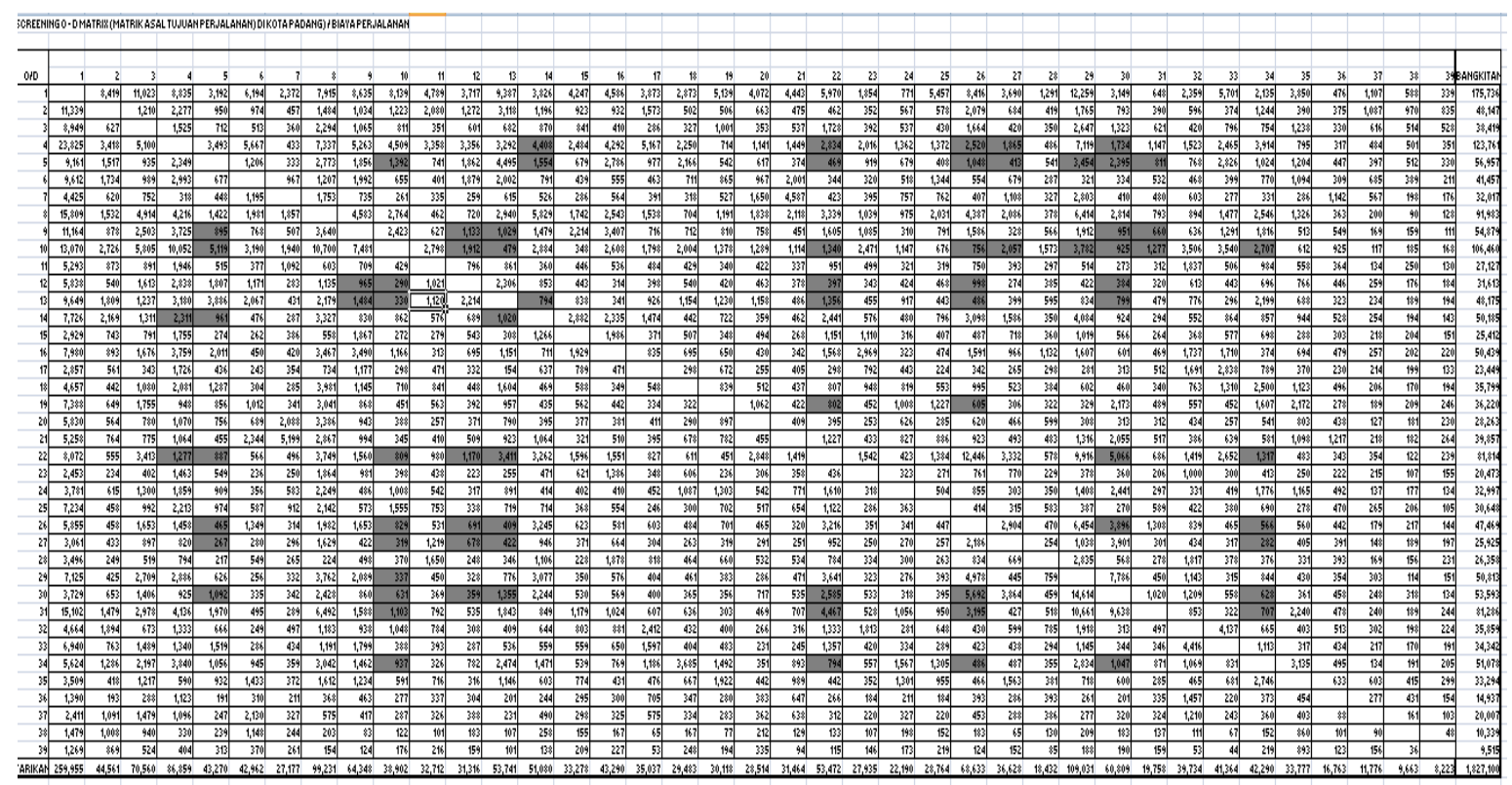

Gambar c. Screening O-D Matrix Berdasarkan Biaya Perjalanan. (Yang diarsir hitam merupakan Zona yang berpeluang multimoda berdasarkan biaya perjalanan) 